\title{
The Construction of Religious and Cultural Identity of Muslim Pupils in Secondary Schools in Britain and France
}

\author{
Sylvie Bernard-Patel \\ Independent Researcher, \\ United Kingdom
}

\section{Doi:10.5901/mjss.2013.v4n7p117}

\begin{abstract}
Emerging from the legacy of colonialism, Britain and France have been the sites of large waves of migration from people whose ethnic origins and religious beliefs vary. A significant proportion is of Islamic faith (about two millions Muslims in Britain and nearly five in France) and attempts to integrate Muslim minorities into the host society reveal differences in the ways the two countries accept cultural diversity and practices. While Britain bases its societal structures around multiculturalism and communitarianism, France fundamentally rejects a society based on communitarianism, advocating its societal structures around the Republican principle and value of laicité [1]. The paper derives from the findings of a cross-national comparative study that examined the educational experience of Muslim pupils and the ways cultural diversity is addressed in Britain and France (Bernard-Patel, 2010). By examining the multicultural environment of British state secondary schools and that of French republican schools, the paper aims to present an account of the ways young Muslim pupils define themselves, their sense of self-identity and the significance of cultural identity within the school environment.
\end{abstract}

Keywords: Britain, France, education, Muslims, cultural identity

\section{Introduction}

Since the end of the Second World War, both Britain and France have had the aim to provide education to all children in order to encourage all individuals to participate in the democratic process. Education fulfils the role of a social equaliser by accentuating learning and raising social recognition and inter-cultural understanding. Used as an 'instrument in pursuit of an egalitarian society' (Halsey, 1965:13), education provides individuals with personal achievement and fulfilment through the acquisition of skills that are needed for the pursuit of a successful working life. However, if education has to be accessible to all, the education system has the responsibility to provide adequate support to those who require it the most: this is especially the case for British Muslims children of South Asian origins and French Muslim children descendants of North African origins (i.e. Maghrebins).

In Britain, there are around half a million Muslim children of school age today. Muslim parents have a number of concerns about the education system including the continuing poor academic results of their children, racism, Islamophobia, bullying, inadequate support for their children's faith and moral education (OSI/EU, 2005:104). One way to improve the situation is through the school curriculum whose role is to promote cross-cultural tolerance by providing greater understanding and a more open approach to Muslim needs. Many Muslim parents, for instance, would appreciate 'the option for their children to receive a form of religious education that gave them more opportunities to enrich their understanding of their own faith as well as studying others' (OSI/EU, 2005:105).

French education has adopted a different approach to that of Britain in educating children of ethnic minorities and particularly French-born children of Maghrebin descendants. Basically, the schools are instructed to make 'no allowance for cultural, linguistic, religious or socio-economic diversity' (Linage, 
2000:73). However, the system presents inequalities in the standards of education with a noticeable lack in performance of ethnic minority children. To improve such discrepancies and the poor achievement of particular schools, additional teachers, security personnel and substitute teachers are allocated to schools in Education Priority Zones in disadvantaged areas. Unfortunately, this supposedly positive action has aggravated the situation by ensuring further ethnic segregation, thus further stigmatising the populations that these measures are meant to serve. On the whole, Muslim children lack official recognition of their religious identity and want to revalorise and display this, exemplified by the issue of the Islamic headscarf. Following repeated social tensions and altercations since 1989 following the 'affaire du foulard' [2], France enacted a law in 2004 banning the wearing of the Islamic headscarf as well as all visible religious symbols at school and in the public sphere in general. The issue regarding the wearing of headscarves in schools highlights the difference between the British and French way of dealing with religious pluralism and cultural differences at school, and most importantly the construction of one' religious and cultural identity.

For the purpose of this paper, I will present some quantitative findings related to the ways young Muslim people articulate, define and position themselves in regards to their sense of self-identity, and the significance of cultural identity in the school environment. Sections 1 and 2 will present an account of the ways Britain and France differ in their education structures, national curriculum, approaches to people of different beliefs or culturally diverse backgrounds. Sections 3 and 4 will present an overview of the position that each country holds in regards to education and Muslim children. Section 5-6 will discuss some quantitative findings in regards to the ways young Muslim participants define themselves and the significance of cultural identity within the school environment.

\section{Study aim and design of the research}

This paper derives from a cross-national comparative study whose goal was to compare the educational experience of Muslim pupils in state schools in Britain and France and the ways cultural diversity is addressed. The research focus was on understanding how the British and French education systems in secondary schools address, answer and accommodate the needs of Muslim pupils. Investigating into secondary state funded schools represent a ground of interest for several reasons. In Britain, secondary schools aim to implement anti-racism and multiculturalism that represent the two axes of the debate on education and ethnic minority groups (Scott, 2007). By acknowledging the separate identity of ethnic minority children, the school represents an appropriate field to examine the question of their interaction with the education system. In France, secondary schools have to treat all children on a neutral stance with regards to religions and ideologies, on the theoretical ground to erase any differences. To meet this objective, structures and strategies are established such as French language is the only language used at school and education rests upon the republican principle of secularism (Chadwick, 1997). Focusing on children aged between eleven and fifteen years of age, quantitative and qualitative methods were used to understand the children's perspective regarding what they believe and feel about their sense of self-identity, their experience of and relationship to school, and more broadly the immediate community and society in general.

\section{Britain: towards a multicultural education structure}

In Britain, the idea of multicultural education started in the 1960s and was based on the ideals of social justice and education equity. In essence, multicultural education:

- recognises that schools are essential to laying the foundation for the transformation of society and the elimination of oppression and injustice (Gorski, 2000).

- helps students from diverse ethnic and religious groups to prepare them for working in a pluralistic society by developing knowledge and skills needed for interactions with people from diverse groups (Banks \& McGee Banks, 1995:xi). 
- shifts new and diverse materials in the curriculum by moving away from the alleged difficulties, socalled 'disabilities', met by children of ethnic minority, to meeting the religious education requirements of the children so that all pupils are well prepared for life in a multicultural society (Swann, 1985).

In 1992, the Government was urged to guarantee that the new school Curriculum would consider the ethnic and religious diversity of British society, emphasising the 'importance of the curriculum in promoting equal opportunity for all pupils regardless of ethnic origin and gender' (Parekh, 2000:142). Hence, the practical implications of a multicultural education started with the National Curriculum, whose selection of content and teaching materials was revisited (teaching material presenting an Anglo-centric view of the world was not favoured).

The school curriculum can play a significant role as far as developing pupils' appreciation for different cultural groups. Although the National Curriculum includes the study of Islamic art, history and literature, most schools do not adequately teach them. For example, the study of Religious Education can provide a better comprehension of the Muslim faith, contributing to overcome intolerance. However, the teaching of the primary religious elements of Islam is usually given by non-Muslims teachers who have little training in Islamic beliefs and values. This brings to the forefront the issue related to teacher training. Out of a four-year undergraduate education degree, "teacher training programmes spend no time on the study of Islam and the needs of Muslim pupils. They do on related issues of racism, inclusion, multicultural education and equal opportunities' (OSI/EU, 2005:153). For this, teachers need specific training around diversity at whole-school, departmental and subject level, to build their confidence around issues of 'identity, race and religion, either in Initial Teacher Training (ITT) or through Continuing Professional Development (CPD) for teachers throughout their career' (DfES, 2007:66-67). In addition, the danger of misrepresenting the religion is more likely to occur when the books and resources employed contain factual inaccuracies and misunderstandings. For example, the Muslim Council of Britain launched in 2004 a 'scheme to provide a resource pack about Islam, for schools to use as a teaching aid'. Although the Muslim Council of Britain contributed to equipping schools with adequate teaching material on Islam faith, Muslim people remained very concerned about the stereotyped opinion that their faith has endured.

The contribution that schools can make towards community cohesion is vital as their role is to promote the equality of opportunity and inclusion of different groups of pupils, as well as promoting shared values and encouraging pupils to engage with others. To achieve this goal, schools are encouraged to develop an approach that will reflect the nature of their population and their location. Since 2008, citizenship education has included the new strand 'Identity and Diversity: Living together in the UK' in which learning about national, regional, ethnic and religious cultures as well as the concept of community cohesion are explored. Drawing from the subjects of History, Geography and Religious Education, Citizenship Education is an interdisciplinary subject whose challenge is for young people 'to develop a notion of citizenship as inclusive, where issues of identity and diversity are addressed explicitly' (DfES, 2007:8).

\section{France: the Republican school}

France has a distinct and centralised Republican tradition, whose identity is consolidated through its school system. As a result, the State plays a large role in defining and implementing education policy and the National Curriculum. Structured around the notion of equality of opportunity, the education system is a vital precondition for social integration and cohesion. Teachers are the responsibility of the central government who attribute them with the status of civil servants. Two thirds of the total funding for the education system (principally teachers' wages but also financial assistance, such as scholarships and allowances) are provided by the state. Since the 1990s, France has been engaged in a process of decentralisation, aiming to bring a more flexible organisation to what was described a homogeneous and large education system. Assigned with greater power, regional and local authorities are now able to decide and treat the issues that affect them, 
independently from Paris or ministerial offices. Every year, Paris accredits a financial budget to the Chief Education Officers, who themselves allocate funds to the various education establishments.

If the role of education is as much the point of correlation between individuals, society and culture to exist to promote social solidarity and social cohesion, then education is the prime instrument for achieving such goals and the State, the sole guarantee to its success. The relationship between the school system and the transmission of culture involves the validation of the cultural capital of the mainstream society and implies that impartiality and universality are often applied within the school system, often to the detriment of the cultural capital of ethnic minority groups. The latter can often be considered insignificant and are excluded altogether from the mainstream education system. Subsequently, in a response to the cultural hegemony transmitted at school, ethnic minority groups are faced with a choice to make as far as their integrative process is concerned. Yet education is also addressed to children whose cultural values differ from the mainstream ones and for which education institutions have to put efforts to assist these children with their inclusion in society.

\section{Education and British Muslim children}

According to the OSI/EU report, 'there are about 500,000 Muslim children currently receiving education in British schools and colleges (i.e. 5-6\% of the total school population). The age profile of Muslims is much younger than any other ethnic group: in all, 33.8\% of Muslims fall into the $0-15$ age bracket (i.e. 1/3 of Muslims are under age 16 as compared with $1 / 5$ of the population as a whole), and a further $18.2 \%$ are between 16 and 24 years old' (OSI/EU, 2005:109). In general, it can be said that the British Muslims have been successful in claiming for equal treatment, opportunity and an acknowledgment of their cultural needs within the realm of educational issues. It was in the 1960s that school authorities began to take notice of the considerable numbers of ethnic minority children and official reactions were encouraged by an 'assimilationist' point of view. On an educational level, this meant giving exclusive priority to the teaching of English and avoiding a situation where the majority in any given class was composed of ethnic minority children. However, assimilationist policies proved to be ineffective as very low academic attainment levels were recorded amongst Muslim children, falling behind their peers and other ethnic minorities (e.g. Hindus and Sikhs). It became apparent that a policy acknowledging the separate identity of ethnic minority children was required.

In the 1990s, the gap between Muslim pupils and the rest continued to grow with education achievements increasing between Indian, African-Caribbean and white children on the one hand, and Pakistani and Bangladeshi children on the other. Muslim parents expressed deep concerns about the values of state education, especially whether the latter reflected aspects of disadvantages and discrimination towards their children. As a result, Muslims proceeded to firm actions for an education aimed to build their children's positive sense of identity, including the right to withdraw children from specifically Christian teaching and the provision of Islamic education suited to their needs (e.g. girls of secondary school age to be allowed to wear modest dress and headscarf conform to the colours of the school uniform). Aspiring to establish independent Muslim schools that had Islam at the heart of the curriculum, this initiative was denied state funding, suggesting to the Muslims that the government was treating them unfairly compared to other religious minorities who were able to secure Voluntary Aided status for their faith-based schools. The pursuit to create Muslim Voluntary Aided schools was more than ever a determined objective and between 1997 and the end of 2001, five Muslim Voluntary Aided schools were approved. This development meant that the request to see independent Muslim schools was potentially achievable. Unfortunately, following the Bradford disturbances of 2001, antagonism against the creation of faith schools resurfaced, putting light on the reality that segregation existed within schools and thus feeding racial tension. Regardless of the contentious climate, Muslim groups maintained their position and claim 'their right to a Muslim education, not only as 
pedagogically appropriate for their children but also as reflective of the multicultural character of British society' (Ansari, 2002:22).

In general, the vast majority of Muslim pupils go to state community schools. The choice is more often driven by residence patterns as Muslim communities, like other ethnic communities, have settled within boroughs of major cities in Britain (e.g. concentration of Muslim children in community schools in London boroughs and other major cities). With a high concentration of Muslim pupils, schools are able to cater for specific requirements of Muslims much better. For example, Local Educations Authorities have granted the following requests from schools with significant Muslim pupils:

the provision of a room for midday prayer and special provision for Friday prayers; the adaptation of school uniform rules and sportswear requirements; the provision of appropriate showering arrangements to take accounts of Islamic teaching about modesty and decency; the use of discretionary holidays to allow Muslim children permission to be away from school at the start of Ramadan and other religious festivals; the provision of halal food for school lunches; single-sex groupings and classes; and sensitivity to Islamic beliefs in assemblies and other school activities' (OSI/EU, 2005:120).

\section{Education and French Muslim children}

Structured and regulated by the principle of laïcité, all children are guaranteed an equal access to education, which is mandatory from the age of six. The analysis of Muslim children can be discussed by looking at the situation in education today for children of ethnic minorities, and more particularly French-born children of immigrant descent. However, some inconsistency appears to exist as pointing out by the OSI/EU Report:

\footnotetext{
'...the principle which affirms the individual right to freedom of conscience has come into conflict, particularly with regard to students belonging to religious minorities, including Muslims. It is a central objective and responsibility of French public schools to train students in Republican values and to ensure equal treatment of individual pupils and respect for pluralism. Local officials have the authority to regulate the public expression of religious belonging in schools. The affair of the headscarf illustrates the tension between public space and private choice, the difficulty in balancing the requirements of laïcité against the needs of Muslim students' (OSI/EU, 2002:92).
}

Schools are mandated to follow the principles of universality (each child must be equipped with same universal knowledge), equality (each child is treated the same) and secularism (religious practices belong to the private life and have no place in school which by definition is in public life). However, it can be said that significant ambivalence within such principles is conspicuous within the issue on diversity in education. For instance, the principle of equality renders it impossible to collect ethnic and racial statistics [3]. Also the term 'ethnic minority nationals' is even rejected within the French system based on the fact that ethnic minorities are not recognised as communities but rather as affiliations of choice. In the interest of equality that prevents differential treatment, the schools are not allowed to collect information on racial, ethnic or religious affiliation of pupils. This rule is enforced even when such information is deemed essential for monitoring and eradicating discrimination and inequalities (Franchi, 2004:3). The French school system addresses cultural diversity by showing no awareness and being non-responsive to children's cultural needs as diversity remains an out-of-school matter (Limage, 2000:85).

Too often, children of ethnic minority backgrounds perform less well on average in secondary education than their peers of French-origin: poor academic achievements, high-level of absenteeism, greater drop-out rate, greater likelihood of them to be involved in delinquency and prone to disciplinary action are the usual way to describe their school achievements. To remedy pupils' discrepancies and poor school achievements, the National Education ministry decided to put in place a 'Priority Education' scheme. This consisted in creating schools in Priority Education Zones (Zone d'Education Prioritaire) associated with socio-economic elements (i.e. unemployment) and cultural elements (i.e. ratio of foreigners and children of migrants attending 
the school). According to the data published by MJENR ${ }^{1}$ (2002), France had in 2001706 Priority Education Zones and during the year, 675,000 pupils (21.5\%) were schooled within Education Priority schools, as compared to $17.9 \%$ in 1999' (cited in Franchi, 2004:36).

Despite efforts to promote school achievement in Priority Education zones, the policies implemented may in fact be part of the root causes of the types of problems encountered regularly (e.g. violence, disciplinary problems and mobility of teachers). In essence, different forms of discrimination take place (e.g. ethnic segregation, stigmatisation, discriminatory discourse of the 'other'), producing inequalities and preventing an integration process within school system.

\section{What does 'cultural identity' mean?}

Each one of us could describe ourselves with a multitude of different identities that can be seen as defining us as people, such as our nationality (e.g. British), our national identity (e.g. Welsh), our origins (e.g. African), our religion (e.g. Muslim), our race (e.g. white, black), our gender (e.g. male, female), our class orientation (e.g. middle-class) or our ideology (e.g. socialist). These notions not only do they often overlap and create some ambiguity on the role and impact they have on identity construction, but they are similarly our own intrinsic and intimate components that make each one of us who we are. Trying to explore the complexity that surrounds the elements that contribute to defining one's cultural identity, is an attempt to better understand what the notion of 'cultural identity' refers to. It can be said that it is a slippery and ambiguous notion because of its multi-dimensional elements (i.e. national, racial, ethnic and religious). If one's self-identity is moulded by one's family and the society one lives in, in a multi-ethnic society complex connections appear to rule the relationships that individuals have with others.

Overall, young Muslim people in both countries have developed a clear sense of self-identity that draws on religion as a source of identification. Figure 1 shows that Islam is highly considered among participants, with $87 \%$ in Britain and $79 \%$ in France. In Figure 2, it is mostly British participants who perceive the role of religion as being very important to them, with $92 \%$ against $72 \%$ for their French counterparts.

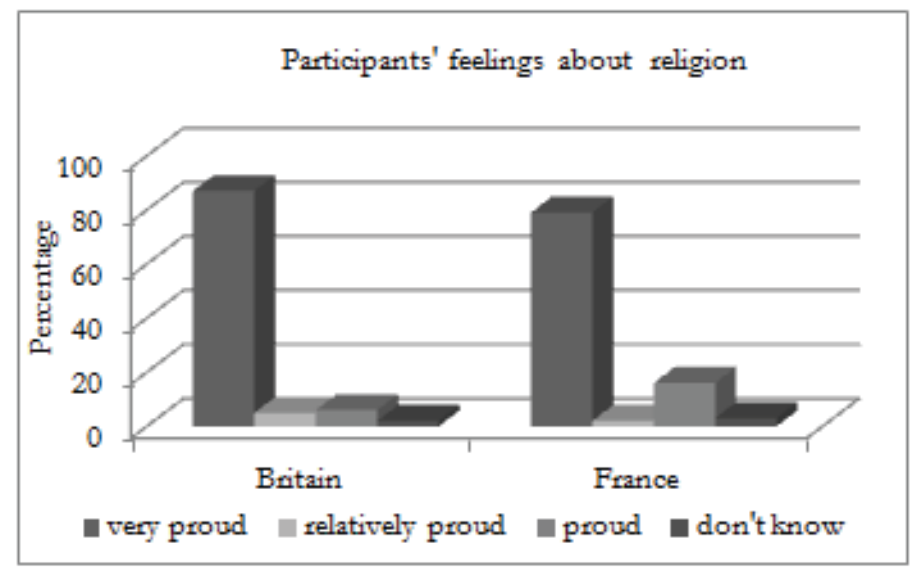

Fig. 1 - Feelings about religion

\footnotetext{
${ }^{1}$ Ministère de la Jeunesse, de l'Education Nationale et de la Recherche (Ministry of Youth, National Education and Research)
} 


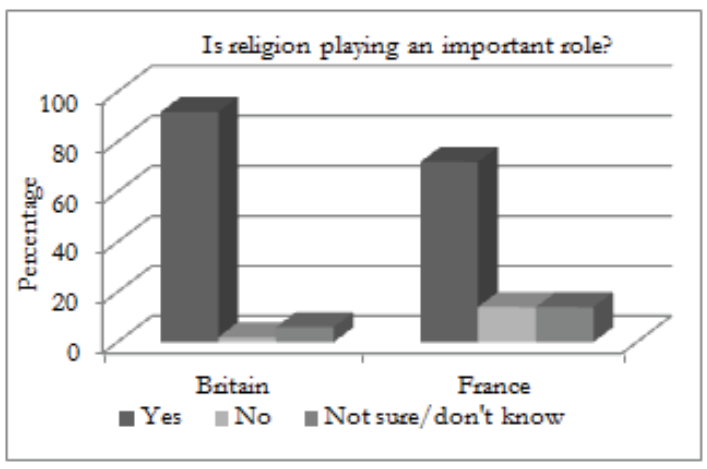

Fig. 2 - Role of religion

Placing religion as the most essential feature in their identity, young participants see themselves as Muslims and are proud and happy about it. Identifying themselves with the Islamic family at large, even when they reside in a non-Muslim country, they show the clear and solid bond that exists through a common belief rather than a nationality or ethnicity. The way young Muslim people make sense of the context in which they define themselves as Muslims shows also the degree society tolerates cultural identity. By developing their perceptions of ethnic/religious belonging, they negotiate new ways of being Muslim in Britain/France. The need to retain aspects of their culture and religion viewed as fundamental to their way of life, while embracing the nationality of the country of residence, raises the notion of belonging.

Table 1 shows the importance that Muslim participants attribute to the way they describe themselves to others. Among the four descriptions (age, gender, nationality and religion), the overall responses from nonMuslim and Muslim participants show that the latter considered religion as the most important way of describing themselves, while the former indicate that it had little bearing on their sense of self-identity.

Table 1 - Relative importance of Age, Gender, Nationality and Religion

\begin{tabular}{|c|c|c|c|c|}
\hline \multirow{2}{*}{} & \multicolumn{2}{|c|}{ Non Muslims } & \multicolumn{2}{c|}{ Muslims } \\
\cline { 2 - 5 } & Percentage & Rank & Percentage & Rank \\
\hline Age & 37 & 2 & 33 & 3 \\
\hline Gender & 40 & 1 & 45 & 2 \\
\hline Nationality & 32 & 3 & 32 & 4 \\
\hline Religion & 21 & 4 & 69 & 1 \\
\hline
\end{tabular}

British and French participants share the views that being Muslim is of great significance, associating with it all the affective aspects that amount to a sense of cultural identity. Reference to the conduct and commitment to live Islam as a system of beliefs, norms and codes translate a defined behaviour associated with becoming a proper Muslim. In addition, traditions and rituals have the function to maintain a common history, culture and collective memories of a community. All participants agree to receive religious education (i.e. learning Arabic and reading the Koran), and performance of faith are significant events for them (i.e. observing Ramadan and celebrating Eid). In general, British participants follow the practice of five daily prayers, acknowledging the school as providers of adequate facilities and the time required conducting this practice. In contrast, French participants experience difficulty in keeping regular practice, because no adequate facilities exist due to the principle of laïcite that schools apply. British and French participants identify the celebration of Ramadan and Eid as special and significant events, considering fasting to be a key indicator of one's status as a Muslim, no matter what gender or age group. While British participants tend to receive greater consideration from their teachers, their French counterparts appear to receive none. 


\section{Significance of cultural identity and school}

Overall, British and French young Muslim people agree that schools do generally care for their cultural needs. However, there are significant differences between what 'accommodating cultural needs' mean to British and French schools. For example, the research revealed that British schools provide halal meals, a prayer room (even a wash room), allow the wearing of headscarves and grant school leave to celebrate Eid. This was not the case in French schools, which only go as far as not serving pork in the canteens and the wearing of headscarves is strictly forbidden. Table 2 shows the opinions elicited in the form of six proposed statements related to school environment.

Table 2 - Views on life at school

\begin{tabular}{|l|l|c|}
\hline \multicolumn{2}{|l|}{ At school, do you think that: } & Strongly agree /Agree (\%) \\
\hline Point A & $\begin{array}{l}\text { Your cultural needs ought to be considered } \\
\text { (e.g. halal food, prayer room) }\end{array}$ & 89 \\
\hline Point B & $\begin{array}{l}\text { Aspects of your cultural traditions ought to be taught at } \\
\text { school }\end{array}$ & 87 \\
\hline Point C & $\begin{array}{l}\text { School ought to be the place to talk openly about your culture } \\
\text { (e.g. organised discussion groups) }\end{array}$ & 74 \\
\hline Point D & Being Muslim does not affect your school life & 77 \\
\hline Point E & You feel that teachers ought to be more aware of your culture & 96 \\
\hline Point F & You would like to be accepted for who you are & 85 \\
\hline
\end{tabular}

Looking at national context, Figure 3 shows that British and French participants firmly express their wish to be accepted at school for who they are (Point F). For the rest of the questions, British participants scored higher than their French counterparts. It is interesting to note that more than two thirds of the French participants feel strongly about their cultural identity and expect the schools to provide for it (Points B and E). Point $C$ is of interest, as $72 \%$ of French participants express an interest in seeing school as a place to talk openly about their culture. This suggests that they have a strong and eager desire to talk overtly about who they are despite the well-understood principle of laïcité at school. However, $71 \%$ of French participants considered their cultural needs to be adequately addressed by the school. On the one hand, this indicates that their expectations have been conformed to laïcité; however on the other hand, they do not know any better and could not envisage anything different. Also of interest is the score of $79 \%$ by British participants on Point $D$, which suggests that there does not appear to be any conflict between school policies and their cultural identity.

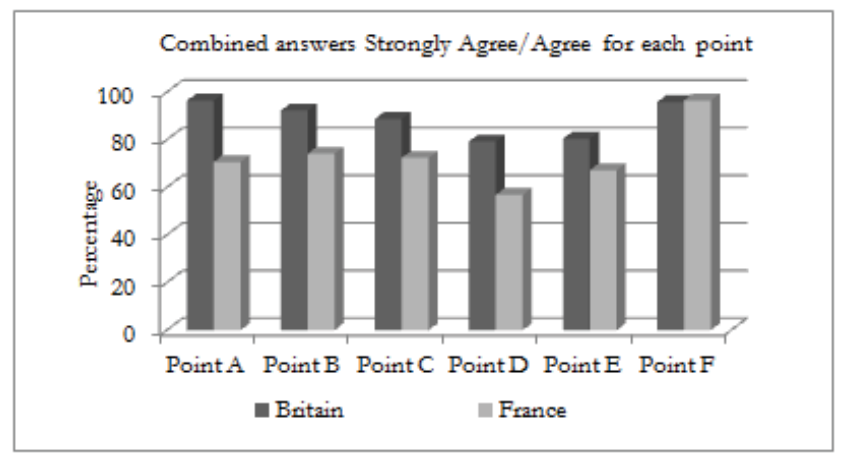

Fig. 3 - Life at school 
British interviewees share positive views about their school as far as their cultural needs are concerned. As important, if not more so, is the concealed curriculum that schools are willing to offer to the needs of their pupils, displaying schools' values and attitudes towards the matter. Schools ought to consider the cultural background from which their pupils come from to avoid possible conflict between specific conditions of religious beliefs and that of the rules and practices of the school (e.g. school policies on dietary customs, school uniform and ethnic dress code). The dominance of the religious dimension in the identity of young British Muslim is of significance in schools, seeing that distinct identities have begun to emerge among Muslims in Britain, most of which have a solid religious dimension. The OSI/EU report suggests that an affirmative recognition of one's ethnic and religious identity may be a prerequisite for education success and consequently the accomplishment of potential and full participation in society (OSI/EU, 2005:146). French participants, on the other hand, considered that the school cares for them as far as not serving pork in canteens and recognise that their school makes an effort. Yet, as no worship facilities exist on school premises, most interviewees go home at lunch time to do their daily prayer.

British participants express happiness and 'feeling comfortable' regarding the school they go to. These positive comments reflect the acknowledged efforts that the schools make towards the Muslim pupils, identifying this as a mark of respect to their religion which, in turn, contributes to their positive attitude towards their school. They also express a sense of safety and a 'homely' feeling, with the knowledge that other people of the same faith are there and able to congregate. One could not imagine a greater contrast to the acknowledged cultural diversity represented in British schools than the Republican school model. For the French participants, the issue of feeling comfortable at school receive no comments. Their remarks concentrate largely on the idea that a prayer room is as much enviable as it is unattainable and claim that the ban on wearing the headscarf and the prohibition about displaying religion are the principal impediments that the school environment imposes upon them.

In British schools, religious diversity is generally accepted in daily life and this is reflected in school life where a set of measures are adopted to adjust to religious expression of identity. This contrast with the fundamental idea of French schools that are perceived as a place that creates a neutral setting in order to offer equal access to education. The fundamental idea that school is the place that creates a neutral setting that offers equal access to education where no influence of religion can be exercised seems defied when liberty, it seems, comes before equality (Sage 2006). It is assumed that school education will provide the individual with emancipatory force that will prevail over sources of oppression rooted in the private sphere (i.e. the family, religious institutions). If state education is the instrument that will promote the individual's autonomy from deeply held religious or communal values, then it can be said that 'the conception of freedom as autonomy is deeply rationalist, intellectualist and often anti-religious' (Laborde 2008, 101-103). This contrasts with the ethos of British schools where a multicultural vision is encouraged, where cultural identities coexist and where diversity is seen as a positive factor.

\section{Conclusion}

Being a young Muslim pupil in Britain and France engages with the realities of living as a minority in a nonMuslim country. No matter what the notion of Muslim identity involves, it will also relate to and embody a prevailing religious characteristic. The research shows that for British and French participants, religion plays a central role in their life.

British and French school systems differ significantly in the way they deal with cultural diversity. In Britain, multicultural education is an approach to teaching and learning based upon consensus building, respect and fostering cultural pluralism. The British model of multiculturalism is the legacy of a political ideal of tolerance for which the basic tenet is a commitment to freedom of conscience. The principle of multiculturalism is the respect for different ethnic, cultural and religious groups in society, with the state making a distinction between the roles of public citizens and their private beliefs. Within this framework, the 
Muslim community is enabled to look at itself from the perspective of others, creating an identity that provides the framework through which they define and relate to other identities. In essence, the objective is to change behaviours and attitudes towards cultural differences and it is believed that the education system is the best place to start.

In contrast, French schools are the epitome of the Republican ideal, where education has to deliver the same promise to all: that is to say liberte from discordant origins whether they are ethnic, religious or classbased; égalité of prospects in a structure aimed at that purpose; and fraternité to newcomers who have joined the social contract (Baumann \& Sunier, 2004:22). It is correct to say that the French education institution has always held a neutral position, whereby no ethnic or religious differences are recognised, embodyng the Republican principle of laïcité. The latter denotes the idea that the state should not be in the business of imposing, advancing or privileging any particular religion, religious belief or religion in general. The emphasis is on the need for citizens to identify and engage with French nationality above individual cultural origins. Within this framework, the Muslim community is absorbed into the idea of neutrality and homogeneity while at the same time they become the symbol of difference undermining the unity of citizens. Within the Republican tradition, the schooling system ought to represent a progressive collectiveness, able to defy racism through the 'French melting pot' project. However, the heterogeneous school population and the growth of issues related to school failure and inequalities reflect that ethnicity has becoming a dimension that can no longer be ignored (Franchi, 2004:45). With invisible official data on the ethnic question, it can be argued that a process of ethnic segregation has been unfolded, with regrettable consequences for children of ethnic minority groups who have become the targets of public stigmatisation, which is directed at their ethnic group.

In general, British Muslim children tend to feel more comfortable at school, acknowledging the attention and respect shown towards their values and beliefs. French Muslim children, on the other hand, do not share in great length their sense of well-being at school. Their cultural background and developed sense of religious belongingness are inherited elements of their culture. Arguing for their right to claim an open acknowledgment of their identity, they speak of their cultural identity in terms of their legacy, their origin.

\section{Notes}

1. In French, laïcité means the absence of religious involvement in government affairs as well as absence of government involvement in religious affairs (Rémond, 1999:150). In other words, the religious is separated from the state, ensuring the neutrality of the state (Law of separation of 1905): the latter cannot impose, advance or privilege any particular religion, religious belief or religion in general. As a legal settlement and an art of living together, laïcité is the pre-requisite necessary for the formation of the republic.

2. The question of the Islamic headscarf first began in the autumn of 1989 , when the headmaster of a secondary school in Creil (north of Paris) refused the admission of three Muslim girls wearing their headscarves. The decision was based on the fact that the wearing of the headscarf was felt as disruptive to the class, a behaviour considered to be an overt sign of overt proselytism.

3. Statistics referring to racial or ethnic origin are forbidden by the country's constitution whose motto advocates liberty, equality and fraternity. The foundation stone of the secular French republic is that all citizens should be equal and free from distinctions of class, race or religion.

\section{References}

Ansari, H., (2002). Report on Muslims in Britain, Minority Rights Group International, London.

Banks, J. A., McGee Banks, C. A., (1995). Handbook of research on multicultural education, Macmillan: New York. 
Baumann, G. and Sunier, T., (2004). The School as a Place in its Social Space. In: G. Baumann et al., Civil Enculturation: Nation-State, Schools and Ethnic Difference in four European Countries, Berghahn Books:Oxford, 21-32.

Bernard-Patel, S., 2010. A comparative study of the education of Muslim pupils and ethnicity in state schools in Britain and France. Thesis (PhD). University of Surrey:UK.

Chadwick, K., (1997). Education in secular France: (re)defining laïcité, in Modern and Contemporary France, 5 (1), $47-59$.

Department for Education and Skills, (2007). Curriculum Review: Diversity \& Citizenship, D35/0107/14, DfES Publication: Nottingham.

Franchi, V., (2004). Rapport Analytique sur l'Education, National Focal Point for France, Agency for the development of intercultural relations, Paris.

Gorski, P., (2000). Defining Multicultural Education, Working Definition, on www.edchange.org

Halsey, A.H., (1965). Education and Equality, in New Society, 17 June, p. 13-5.

Laborde, C., 2008. Critical Republicanism: The Hijab Controversy and Political Philosophy. Oxford: Oxford University Press.

Liederman, L. M., (2000). Religious Diversity in Schools: the Muslim Headscarf Controversy and Beyond, Social Compass, 47 (3), 367-381.

Limage, L. J., (2000). Education and Muslim identity: the case of France, Comparative Education, 36 (1): 73-94.

OSI/EU, (2002). Monitoring the EU Accession Process: Minority Protection Volume II - Case Studies in Selected Member States, Open Society Institute/EU Accession Monitoring Program, Hungary.

OSI/EU, (2005). Muslims in the UK: Policies for Engaged Citizens, Open Society Institute/EU Monitoring and Advocacy Program Hungary.

Parekh, B. C., (2000). Rethinking Multiculturalism: Cultural Diversity and Political Theory, Macmillan: Basingstoke.

Rémond, R., (1999). Religion and Society in Modern Europe, Blackwell Publishers, Malden: MA.

Sage, A., (2006). Return of the school uniform, from The Times, 21st June 2006, available on www.timesonline.co.uk Scott, J.W., (2007). The Politics of the Veil, Princeton University Press: Princeton.

Swann Report (1985). Education For All: The Report of the Committee of Inquiry into the Education of Children from Ethnic Minority Groups, Her Majesty's Stationery Office: London. 
